\title{
Application of the method of complex assessment of the quality of high rise apartment buildings in practice
}

\author{
Yana Shesterikova* \\ Moscow State University of Civil Engineering, 129377, Moscow, Russia
}

\begin{abstract}
A comprehensive approach to the problem of improving the quality of construction of residential buildings, allows you to take into account various main factors that affect the quality of construction in General. Using the method of expert opinions, the most significant parameters were identified. The weight of each factor is determined using a mathematical model. The experiment examined three levels of variation in significance for each group of factors. After obtaining a discrete value of a complex indicator of the quality of construction of a residential building, it is interpreted using adapted quantitative ranges of values of the generalized Harrington desirability function. A method has been developed to determine the effectiveness of organizational and technological decisions made. An algorithm has also been developed to improve the quality of residential building construction.
\end{abstract}

\section{Introduction}

After analyzing Russian and foreign literature, the author identifies the main parameters that affect the quality of a multi-story building object.

Further, according to the results of a survey of experts, the most significant of them the following are 8 parameters:

- technical specifications for the facilities $\left(\mathrm{P}_{1}\right)$;

- A reliable and complete volume of materials, including all sections on engineering surveys $\left(\mathrm{P}_{2}\right)$;

- compliance with organizational and technical decisions $\left(\mathrm{P}_{5}\right)$;

- compliance with the sequence of work $\left(\mathrm{P}_{6}\right)$;

- geotechnical monitoring $\left(\mathrm{P}_{7}\right)$;

- the presence of lifting mechanisms $\left(\mathrm{P}_{8}\right)$;

- application of industrial formwork systems $\left(\mathrm{P}_{10}\right)$;

- the use of modern equipment with high performance $\left(\mathrm{P}_{11}\right)$;

In the course of further studies, for the selected eight factors, according to the calculation results, an intercorrelation matrix was compiled.

\footnotetext{
*Corresponding author: shesterikova.jana@yandex.ru
} 
Based on the results of the analysis of the intercorrelation matrix, 4 groups of wellinterconnected variables $\left(\mathrm{z}_{1}, \mathrm{z}_{2}, \mathrm{z}_{3}\right.$ and $\left.\mathrm{z}_{4}\right)$ were identified.

Due to the fact that this experiment is multifactorial, it is necessary to search for a mathematical model that is a regression equation that adequately describes the results of the experiment.

Based on the research, the most appropriate model is the General quadratic model (coefficient of determination 0.965):

$$
\begin{gathered}
Y=54,83+8,89 z_{1}+9,45 z_{2}+5,83 z_{3}+5.83 z_{4}+0,2 z_{1}^{2}+5,2 z_{2}^{2}+ \\
2,7 z_{3}^{2}+2,7 z_{4}^{2}-2,5 z_{1} z_{2}-1,25 z_{1} z_{4}+1,86 z_{2} z_{3}-1,86 z_{2} z_{4}-3,12 z_{3} z_{4}
\end{gathered}
$$

The resulting second-order regression equation is a mathematical model of the process under study.

The mathematical model allows you to make adjustments to achieve the desired levels of reliability, quality, and durability at any stage of any construction project.

The use of a mathematical model that reflects the essence of the phenomenon we are considering in the final result is the optimal solution, allows us to successfully predict and evaluate the impact of individual factors on a complex quality indicator.

In future calculations, a complex quality indicator that is determined not by groups of factors, but by its parameters will be referred to as the CPR.

Getting a detailed mathematical model based on a certain functional dependence that allows you to get the values of the CPR, the method of modeling factor systems is used, on the basis of which we get an expression of the form:

$$
\mathrm{CPR}=\sum_{\mathrm{i}=1}^{\mathrm{n}} \mathrm{W}_{\mathrm{i}} \mathrm{pi},
$$

where $\mathrm{Wi}$ is the importance factor (weight); $\mathrm{i}$-th parameter;

The resulting model not only fully characterizes the process of studying a complex quality indicator, but also allows it to be upgraded in order to complicate or simplify the process.

\section{Analysis parametrical indicators}

As part of the experiment, three levels of significance variation were considered for each group of factors (regression equation variables).

It should be emphasized that the number of levels of variation and the number of variables can be an indefinite number.

To be able to use the calculated mathematical model in the described experimental process, it is important that the sum of the values for all parameters corresponds to the control points on the plan of the experiment.

Select Y1, Y16, and Y25 as control points.

Point of the plan Y1 (91.25) absolutely all groups of parameters are determined by the upper levels of significance;

Plan point Y16 (27.5) - all significance levels are lower;

Point of the plan Y25(58.12) - absolutely all groups of parameters are determined by the main (zero) levels of significance.

Due to the fact that the total value of the weights of the parameters of the organizational and management model has a value of 1 , to bring mathematical model in analogy with experimental data, there is a need to adopt the values of the lower level of the parameter of the organizational management model 27,5; main level value will be made equal 58,12 ; the top-level value will be made equal 91,25. 
Taking into account the above, we will make table 1.

Table 1. Factors and levels of variation

\begin{tabular}{|c|c|c|c|c|c|}
\hline № & Name of factors & $\begin{array}{l}\text { Symbol of } \\
\text { the factors }\end{array}$ & $\begin{array}{l}\text { Levels of parameter } \\
\text { variation }\end{array}$ & Value & Value code \\
\hline 1. & $\begin{array}{l}\text { Proper urban plan } \\
\text { of the land } \\
\text { plot, which } \\
\text { reflects all the } \\
\text { comprehensive } \\
\text { information }\end{array}$ & $\mathrm{P}_{1}$ & $\begin{array}{l}\text { - presence of all } \\
\text { elements and the full } \\
\text { material volume; } \\
\text { - lack of separate } \\
\text { elements and of } \\
\text { individual reports } \\
\text { - absence of most } \\
\text { elements and in } \\
\text { incomplete volume }\end{array}$ & $\begin{array}{l}91.25 \\
58.12 \\
27.5\end{array}$ & $\begin{array}{l}3 \\
2 \\
1\end{array}$ \\
\hline 2. & $\begin{array}{c}\text { Technical } \\
\text { conditions for all } \\
\text { objects }\end{array}$ & $\mathrm{P}_{2}$ & $\begin{array}{l}\text { - present and full } \\
\text { compliance with the } \\
\text { requirements } \\
\text { - partially present and } \\
\text { partially compliant } \\
\text { - not present and do } \\
\text { not comply }\end{array}$ & $\begin{array}{l}91.25 \\
58.12 \\
27.5\end{array}$ & $\begin{array}{l}3 \\
2 \\
1\end{array}$ \\
\hline 3. & $\begin{array}{l}\text { Use of modern } \\
\text { equipment with } \\
\text { high accuracy of } \\
\text { all operations } \\
\text { and performance }\end{array}$ & $\mathrm{P}_{5}$ & $\begin{array}{l}\text { - used; } \\
\text { - partially used; } \\
\text { - not used. }\end{array}$ & $\begin{array}{c}91.25 \\
58.12 \\
27.5\end{array}$ & $\begin{array}{l}3 \\
2 \\
1\end{array}$ \\
\hline 4. & $\begin{array}{l}\text { Compliance of } \\
\text { design solutions } \\
\text { with the } \\
\text { requirements of } \\
\text { the normative } \\
\text { and technical } \\
\text { documentations } \\
\text { in effect at the } \\
\text { time of the } \\
\text { examination }\end{array}$ & $\mathrm{P}_{6}$ & $\begin{array}{l}\text { - full compliance with } \\
\text { the requirements; } \\
\text { - partially correspond; } \\
\text { - not correspond. }\end{array}$ & $\begin{array}{l}91.25 \\
58.12 \\
27.5\end{array}$ & $\begin{array}{l}3 \\
2 \\
1\end{array}$ \\
\hline 5. & $\begin{array}{c}\text { Use of vertical } \\
\text { transport in the } \\
\text { project }\end{array}$ & $\mathrm{P}_{7}$ & $\begin{array}{l}\text { - vertical transport is } \\
\text { designed for greater } \\
\text { comfort of residents; } \\
\text { - vertical transport is } \\
\text { designed to meet the } \\
\text { regulation requirements; } \\
\text { - vertical transport is } \\
\text { designed with insufficient } \\
\text { volume to lift the } \\
\text { residents of the house. }\end{array}$ & $\begin{array}{l}91.25 \\
58.12 \\
27.5\end{array}$ & $\begin{array}{l}3 \\
2 \\
1\end{array}$ \\
\hline
\end{tabular}




\begin{tabular}{|c|c|c|c|c|c|}
\hline 6. & $\begin{array}{c}\text { Fire prevention } \\
\text { measures }\end{array}$ & $\mathrm{P}_{8}$ & $\begin{array}{c}\text { - fire prevention measures } \\
\text { are designed to exceed the } \\
\text { requirements of } \\
\text { regulations for greater } \\
\text { safety of residents of the } \\
\text { house; } \\
\text { - fire prevention } \\
\text { measures are } \\
\text { developed in } \\
\text { accordance with } \\
\text { regulations; } \\
\text { - fire prevention measures } \\
\text { are not fully } \\
\text { implemented, that's why } \\
\text { special technical } \\
\text { conditions have been } \\
\text { developed. }\end{array}$ & $\begin{array}{r}91.25 \\
58.12 \\
27.5\end{array}$ & 3 \\
\hline 7. & $\begin{array}{c}\text { Availability of } \\
\text { lifting } \\
\text { mechanisms }\end{array}$ & $\mathrm{P}_{10}$ & $\begin{array}{c}\text { - at the site there are } \\
\text { cranes, cargo and } \\
\text { passenger lifts and other } \\
\text { mechanisms for concrete } \\
\text { pumping; } \\
\text { - at the site there are } \\
\text { cranes and passenger lifts; } \\
\text { - on the construction site } \\
\text { there are cranes that } \\
\text { perform all types of lifts } \\
\text { work. }\end{array}$ & $\begin{array}{l}91.25 \\
58.12\end{array}$ & 3 \\
\hline 8. & $\begin{array}{c}\text { Types of } \\
\text { installation }\end{array}$ & $\mathrm{P}_{11}$ & $\begin{array}{l}\text { - installation from wheels, } \\
\text { availability of open, } \\
\text { closed unheated and } \\
\text { heated warehouses; } \\
\text { - the installation of the } \\
\text { wheels and the } \\
\text { presence of a small } \\
\text { open storages; } \\
\text { - mounting from } \\
\text { wheels. }\end{array}$ & $\begin{array}{r}91.25 \\
58.12 \\
27.5\end{array}$ & 3 \\
\hline
\end{tabular}

After obtaining a dimensionless discrete value for the construction of a multi-storey residential building for its qualitative interpretation, it is necessary to adapt the "use of quantitative ranges of values of the generalized Harrington desirability function" (table 2) to the specific ones.

Table 2. The relationship between the quantitative values of the dimensionless scale and the psychological perception of a person

\begin{tabular}{|c|c|}
\hline Desirability & Quantitative mark on the desirability scale \\
\hline Very well & $0.80-1.00$ \\
\hline Good & $0.63-0.80$ \\
\hline Satisfactorily & $0.37-0.63$ \\
\hline Bad & $0.20-0.37$ \\
\hline Very bad & $0.00-0.20$ \\
\hline
\end{tabular}

Further, the adapted quantitative ranges of function values in a qualitative interpretation, based on the similarity principle, are presented in table 3 . 
Table 3. Converting a quantitative assessment to a qualitative one

\begin{tabular}{|c|c|c|c|}
\hline № & $\begin{array}{c}\text { Gradatio of } \\
\text { values }\end{array}$ & $\begin{array}{c}\text { Gradation scale of } \\
\text { desirability }\end{array}$ & Psychophysical assessment \\
\hline 1 & $<80$ & $0.80-1.00$ & Very well \\
\hline 2 & $60-80$ & $0.63-0.80$ & Good \\
\hline 3 & $54.83-60$ & $0.37-0.63$ & Satisfactorily \\
\hline 4 & $30-54.82$ & $0.20-0.37$ & Bad \\
\hline 5 & $0-29$ & $0.00-0.20$ & Very bad \\
\hline
\end{tabular}

Due to the fact that the quantitative range of values that have qualitative interpretations of the function values: "Good" and " Very good "and" Bad "and" Very bad " have the same semantic load for construction, they must be combined.

The final table of qualitative interpretation of the discrete assessment of the quality of multi-storey residential buildings is presented in table 4 .

Table 4. Converting a quantitative assessment to a qualitative one

\begin{tabular}{|c|c|c|c|}
\hline № & $\begin{array}{c}\text { Gradation of } \\
\text { values }\end{array}$ & Gradation scale of desirability & Desirability scale \\
\hline 2 & $<60$ & $0.63-1.00$ & Good \\
\hline 3 & $54.83-60$ & $0.37-0.63$ & Satisfactorily \\
\hline 4 & $>54.82$ & $0.00-0.37$ & Bad \\
\hline
\end{tabular}

All CPR values below 54.82 will indicate an unsatisfactory state of the construction company's organizational and management system.

With the creation of a comprehensive assessment and algorithms for calculating the CPR, a description of the methodology for a comprehensive assessment of the quality of multi-storey residential buildings was made:

1. Monitoring of organizational and technical solutions that are involved in the construction of a multi-storey residential building, taking into account compliance with current standards;

2. The ratio of organizational and technical solutions, taking into account the parameters that are given in a tabular form;

3. Determination of a complex indicator of the quality of a multi-storey residential building;

4. Already the value obtained properly correlate with the tabulated data qualitative interpretation of a discrete valuation, with the definition of qualitative assessment developed organizational and technical solutions.

If you have identified an unmet assessment of the quality, it is possible to resort to the use of such techniques as:

1. implementation of measures that will help to achieve a significant improvement in the quality indicator while minimizing financial costs and possible adverse consequences for the Customer;

2. Calculations of new values of updated indicators;

3. Re-definition of the indicator;

4. Re-correlation of the criterion with tabular data of qualitative interpretation to determine the qualitative assessment of already approved organizational and technical solutions.

If the customer is still not satisfied with the value of the indicator, you can use repeating the algorithm until the work meets all the requirements. 


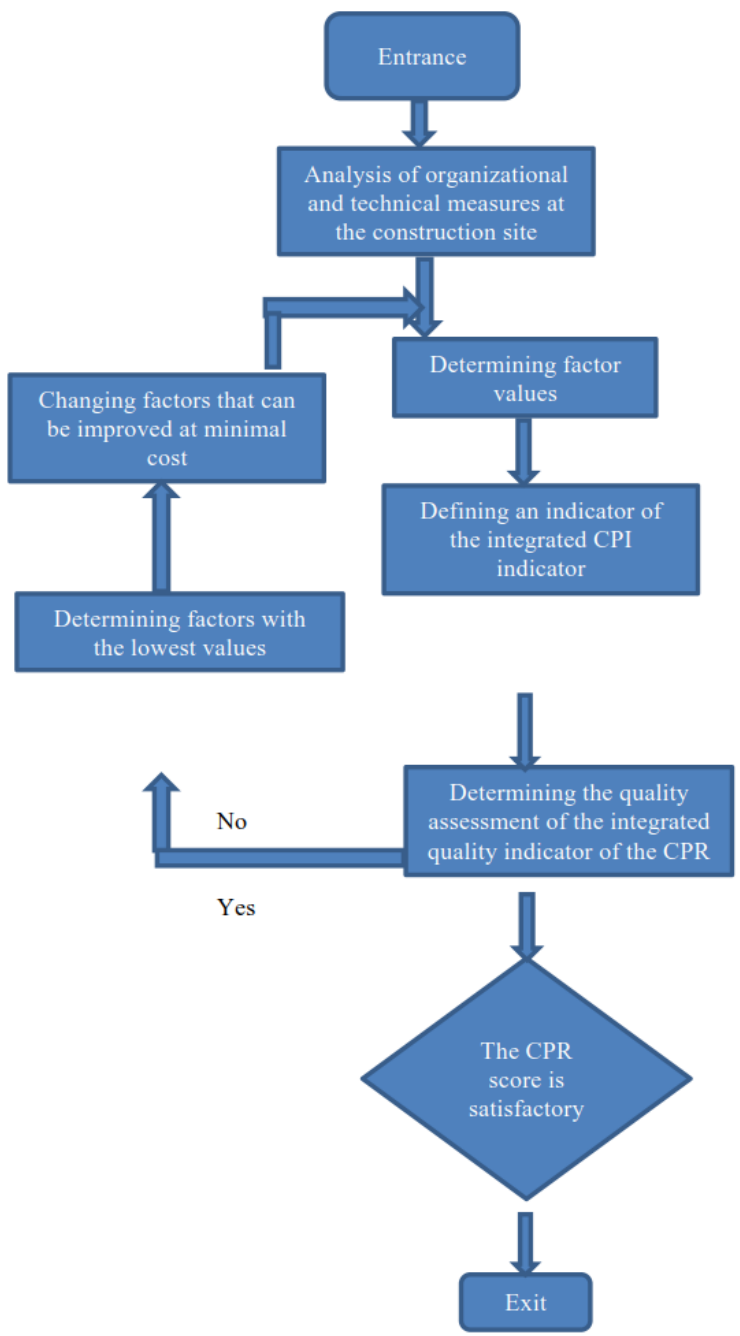

Fig. 1. Algorithm for calculating and improving the complex efficiency indicator of the CPR

As part of the implementation on real construction sites, the real significance of the methodology developed by the author is established and proved.

This method is a full-fledged tool for construction participants, allowing them to determine the quality level at various stages of a construction project using such a tool as the "integrated quality indicator of multi-storey residential buildings", as well as to adjust organizational and technical solutions if necessary.

\section{References}

1. A. Czajkowska, M. Kadłubek, Management of factors affecting quality of processes in construction enterprises, Polish journal of management studies 11(1), 28-38 (2015)

2. Min Liu, Glenn Ballard, and William Ibbs, Work Flow Variation and Labor Productivity: Case Study, Journal of Management in Engineering 27(4), 236-242 (2011) 
3. V.V. Efimov, Statistical methods in quality management (U1STU, Ulyanovsk, 2003)

4. A.A. Lapidus, P.A. Govorukha, Organizational and technological potential of the enclosing structures of multi-storey residential buildings, Vestnik MGSU 4, 143-149 (2015)

5. A.A. Lapidus, I.V. Shesterikova, Development of a mathematical model for complex quality indicator evaluation in the construction of multi- storey residential buildings, Science and business: ways of development 91(1), 43-48 (2019)

6. A. Lapidus, I. Abramov, Formation of production structural units within a construction company using the systemic integrated method when implementing high-rise development projects, E3S Web of Conferences, D. Safarik, Y. Tabunschikov and V. Murgul (Eds.), 03066 (2018)

7. D.V. Topchiy, Organizational and technological modeling of construction and installation works in a comprehensive assessment of the effectiveness of re-profiling of industrial facilities ( $\mathrm{PhD}$ thesis-Moscow, 2015)

8. R.Y. Sunindijo, B.H.W. Hadikusumo, \& T. Phangchunun, Modelling service quality in the construction industry, International Journal of Business Performance Management 15(3) 262-276 (2014).

9. H. Mallawaarachchi and S. Senaratne, Importance of Quality for Construction Project Success, International conference on structural and construction management, 84-89. (2015)

10. A.A. Gusakov, Yu.M. Bogomolov, A.I. Brekhman, G.A. Vahanyan, System Engineering of construction (edited by A. A. Gusakov. 2nd ed., add., pererab., ASV Publishing house, M., 2004)

11. A.A. Lapidus, A.Yu. Berezhny, Mathematical model for evaluating the generalized indicator of environmental load during construction project, Vestnik MGSU 2, 30-33 (2012)

12. Sevilay Demirkesen, Beliz Ozorhon, Impact of integration management on construction project management performance, International Journal of Project Management 35, 1639-1654 (2017)

13. A.A. Lapidus, I.V. Shesterikova, Mathematical model for assessment the potential of the high-rise apartment buildings complex quality index, E3S Web of Conferences 91, 02025 (2019) TPACEE-2018 doi.org/10.1051/e3sconf/20199102025 TPACEE-2018

14. A.I. Kobzar, Applied Mathematical Statistics. For engineers and scientists (FIZMATLIT, M., 2006)

15. V.P. Shulenin, Robust methods of mathematical statistics. Tomsk, NTL Publishing house, 2016.

16. Lagutin M. B., Visual mathematical statistics (2nd ed., Rev., M., 2009)

17. Experimental and statistical models. Experiment planning and regression analysis of results. Using the Harrington desirability function in solving optimization problems of chemical technology, Moscow, rkhtu-2003, 89 p. 